\title{
PERANCANGAN SISTEM E-LEARNING BERBASIS WEB PADA WORLD VISION INDONESIA
}

\author{
Agus Putranto \\ Information Systems Department, School of Information Systems, Binus University \\ Jln. K.H. Syahdan No. 9, Palmerah, Jakarta Barat 11480 \\ aputra@binus.edu
}

\begin{abstract}
World Vision Indonesia has several training programs with a very large total cost for 936 employees located in various parts of Indonesia, so that the manual training is considered less effective. Therefore, this research is conducted to design a learning management system application that supports the training process within the organization, and determine the needs for training materials. This research implemented strategy analysis based on matrix EFE, IFE, SWOT, IE, and QSPM, as well as analysis and design of materials using Addie model. Meanwhile the design used a structured design method or OOAD. This research resulted in an application that supports the learning management system training process within the organization, provides accessible training materials by all employees at any time, and provides various features that creates training activities more effectively. The implementation of learning management system supports the company's strategy primarily to improve the quality of employees as well as reduces communication barriers between trainers and trainees both within and outside of training time.
\end{abstract}

Keywords: training materials, organization, World Vision Indonesia, learning management system

\begin{abstract}
ABSTRAK
World Vision Indonesia memiliki beberapa program pelatihan dengan total biaya yang sangat besar untuk 936 karyawan yang tersebar di berbagai pelosok Indonesia, sehingga pelatihan secara manual dinilai kurang efektif. Oleh karena itu penelitian ini dilakukan untuk merancang aplikasi learning management system yang mendukung proses pelatihan dalam organisasi, serta menentukan kebutuhan materi pelatihan. Penelitian ini menggunakan metode analisis stategi berdasarkan matriks EFE, IFE, SWOT, IE, dan QSPM, serta analisis dan perancangan materi dengan ADDIE model. Sedangkan perancangan menggunakan metode perancangan terstruktur atau OOAD. Penelitian ini menghasilkan aplikasi learning management system yang mendukung proses pelatihan dalam organisasi, menyediakan materi pelatihan yang dapat diakses oleh seluruh karyawan setiap saat, serta menyediakan berbagai fitur yang menjadikan kegiatan pelatihan lebih efektif. Penerapan learning management system mendukung strategi perusahaan terutama untuk meningkatkan kualitas karyawan dan mengurangi hambatan komunikasi antara trainer dan trainee baik di dalam maupun di luar waktu pelatihan.
\end{abstract}

Kata kunci: materi pelatihan, organisasi, World Vision Indonesia, learning management system 


\section{PENDAHULUAN}

Pelatihan bagi karyawan bukanlah sesuatu yang mudah dilakukan, apalagi jika perusahaan memiliki banyak cabang di berbagai daerah. Solusi untuk permasalahan ini dapat diselesaikan dengan pemanfaatan teknologi informasi khususnya internet. Dengan adanya internet, karyawan dapat melakukan proses pembelajarannya tanpa batas ruang dan waktu. Metode pembelajaran dengan menggunakan internet ini lebih dikenal dengan $e$ - learning. Penggunaan $e$ - learning di perusahaan lokal maupun internasional sudah menjadi kebutuhan yang mendesak, karena adanya harapan agar karyawan dapat membawa organisasi ke arah yang lebih maju sesuai dengan visi dan misi organisasi, meningkatkan efisiensi pekerjaan dalam organisasi, dan menurunkan biaya, terutama biaya pelatihan.

World Vision adalah organisasi yang bergerak di bidang sosial. Organisasi ini mulai berdiri pada tahun 1950, dan membuka kantor pertamanya di Indonesia pada tahun 1960. World Vision Indonesia tersebar di berbagai propinsi seperti Papua, Aceh, Sumatera Utara, Sulawesi Tengah, DKI Jakarta, Jawa Timur, Kalimantan Barat, dan Nusa Tenggara Timur. Kegiatan yang dilakukan meliputi program santunan anak, peningkatan taraf hidup dalam kesehatan, pendidikan, dan ekonomi masyarakat. Seiring berjalannya waktu, organisasi ini menginginkan pelaksanaan proses kerja dalam perusahaan berjalan dengan baik. Proses kerja yang baik harus ditunjang dengan karyawan yang memiliki kemampuan di bidangnya masing- masing, sehingga diperlukan suatu training atau pelatihan untuk karyawan tersebut.

World Vision Indonesia membagi pelatihannya ke dalam tiga program, yaitu pelatihan I-Learn, orientasi staff, dan training operasional. Program pelatihan I-Learn merupakan suatu pelatihan massal yang mengumpulkan seluruh kantor proyek atau project field World Vision yang tersebar di berbagai propinsi di Indonesia, seperti Papua, Aceh, Sumatera Utara, Sulawesi Tengah, DKI Jakarta, Jawa Timur, Kalimantan Barat, dan Nusa Tenggara Timur, untuk berkumpul di Jakarta. Program orientasi staff merupakan suatu pelatihan bagi karyawan baru, yang berupa pelatihan selama tiga bulan yang terbagi atas pelatihan satu bulan di ruangan kelas dan dua bulan di lapangan. Sedangkan program training operasional merupakan pelatihan yang diberikan agar karyawan mampu menjalankan tugas operasionalnya dengan baik. Pada program training operasional ini masing- masing karyawan akan diberikan pelatihan sesuai dengan bidang pekerjaannya. Selain itu, karyawan juga diberikan kuota untuk mengikuti tiga seminar dari luar organisasi. Total biaya ketiga pelatihan sangat besar karena World Vision memiliki 936 karyawan. Untuk menekan biaya pelatihan, dan agar pelatihan bisa berlangsung secara lebih efisien yang pada akhirnya akan meningkatkan kinerja karyawan, World Vision Indonesia membutuhkan penerapan $e$ - learning.

Dengan penerapan e-learning yang mengembangkan learning management system, World Vision Indonesia dapat menyebarkan materi pelatihan yang dibutuhkan karyawannya dengan lebih cepat tanpa dibatasi oleh batas ruang dan waktu, serta mampu meningkatkan komunikasi antara trainer dan trainee baik selama waktu pelatihan, maupun di luar waktu pelatihan. Selain itu, dengan pelaksanaan pelatihan secara online, pelatihan secara manual dapat dikurangi yang akhirnya dapat mengurangi biaya pelatihan.

Ruang lingkup penulisan ini adalah: (1) berfokus dalam proses analisis dan perancangan, sedangkan untuk proses implementasi dan evaluasi merupakan rencana yang akan dilaksanakan; (2) membahas mengenai strategi yang tepat untuk diterapkan oleh organisasi dengan menganalisis lingkungan eksternal dan internal organisasi; (3) menganalisis sistem yang berjalan, serta keterkaitannya dengan kinerja yang hendak dicapai oleh organisasi; (4) berfokus pada pembuatan learning management system sebagai penyedia materi yang sesuai dengan kebutuhan karyawan dalam World Vision Indonesia. 
Adapun tujuan dari penulisan ini adalah: (1) mengidentifikasi kebutuhan materi yang dibutuhkan oleh karyawan World Vision Indonesia; (2) merancang aplikasi learning management system pada World Vision Indonesia. Sementara manfaat dari penulisan ini adalah: (1) World Vision Indonesia dapat mengetahui apa yang dibutuhkan oleh karyawannya; (2) memperkenalkan sistem pelatihan berbasis web yang berupa learning management system kepada karyawan World Vision Indonesia; (3) mempermudah pengembangan aplikasi learning management system bagi organisasi World Vision Indonesia.

\section{Landasan Teori}

\section{E-Learning}

Menurut Ruth (2010), kita dapat mengetahui untung rugi dari penerapan e-learning, dimana penerapan e-learning bukan berarti akan menghemat biaya, namun membutuhkan biaya yang besar untuk implementasinya seperti biaya pengadaan jaringan, server, maupun infrastruktur teknologi yang lainnya. Selain itu belum tentu semua pihak dalam organisasi mendukung $e$ - learning tersebut karena ada beberapa pihak yang takut pekerjaan dan kekuasaan mereka akan terancam dengan adanya $e$ learning ini.

Berdasarkan Tsai (2010), e-learning digunakan untuk dapat menyampaikan materi pelajaran atau pelatihan tanpa adanya batasan tempat dan waktu, yang pada akhirnya akan meningkatkan kualitas dari proses pelatihan tersebut. Untuk mencapai kualitas dari pelatihan juga dibutuhkan kolaborasi dari berbagai jenis e- learning baik yang bersifat synchronous maupun asynchronous.

E-Learning mengacu pada semua kegiatan pelatihan yang menggunakan media elektronik atau teknologi informasi. (Effendi dan Zhuang, 2005). Ada dua tipe E-Learning: (1) synchronous learning, adalah istilah yang mengacu pada sekumpulan orang yang melakukan pembelajaran pada saat yang sama di tempat yang berbeda. Synchronous training mengharuskan guru dan murid untuk mengakses internet secara bersamaan; (2) asynchronous learning, yang berarti tidak pada waktu yang bersamaan. Metode pembelajaran ini dilakukan pada waktu yang berbeda-beda, dari tempat yang berbeda-beda pula. Asynchronous learning adalah metode pembelajaran berfokus pada siswa yang menggunakan sumberdaya pembelajaran secara online untuk memfasilitasi pembagian informasi di luar batas waktu dan tempat pada jaringan orang-orang yang berbeda.

Menurut Effendi dan Zhuang (2005, pp9-17) keuntungan yang ditawarkan oleh e-learning antara lain adalah menekan biaya pelatihan, fleksibilitas waktu, fleksibilitas tempat, fleksibilitas kecepatan pembelajaran, standarisasi pengajaran, efektifitas pengajaran, kecepatan distribusi materi, dan otomatisasi proses administrasi. Walaupun e-learning menawarkan banyak keuntungan bagi organisasi, praktiknya juga memiliki beberapa keterbatasan yang harus diwaspadai yaitu: (1) budaya penggunaan e-learning menuntut self- learning, di mana seseorang memotivasi diri sendiri agar mau belajar. Sebaliknya pada sebagian besar pelatihan di Indonesia, motivasi belajar lebih banyak tergantung pada pengajar; (2) investasi - walaupun e-learning menghemat biaya, suatu organisasi harus mengeluarkan investasi awal cukup besar untuk mulai mengimplementasikan e-learning. Implementasi dapat berupa biaya perancangan dan pembuatan program learning management system, paket pelajaran, dan biaya lain- lain seperti promosi dan change management system. Apabila infrastruktur belum memadai, organisasi harus mengeluarkan sejumlah dana untuk membeli komputer, jaringan, dan server; (3) teknologi - karena teknologi yang digunakan beragam, ada kemungkinan teknologi tersebut tidak sejalan dengan teknologi yang sudah ada dan terjadi konflik teknologi sehingga e-learning tidak berjalan dengan baik; (4) infrastruktur - internet belum menjangkau seluruh kota di Indonesia. Layanan Broadband (media yang dapat dilalui berbagai macam layanan, tidak hanya internet, tetapi juga voice, komunikasi data perkecepatan lebih dari $10 \mathrm{Mbps}$ ) baru tersedia di kota- kota besar. Akibatnya, belum semua orang atau wilayah dapat merasakan $e$ - learning dengan internet; (4) materi - walaupun internet menawarkan berbagai fungsi, ada beberapa materi yang tidak 
dapat dijalankan melalui e-learning. Pelatihan yang membutuhkan banyak kegiatan fisik, seperti olah raga dan instrument musik sulit disampaikan melalui e-learning secara sempurna.

\section{ADDIE (Analyze, Design, Develop, Implement, and Evaluate)}

Materi atau content yang tersedia dalam LMS merupakan hasil analisis dari kebutuhan materi pelatihan, dimana analisis kebutuhan materi menggunakan metode ADDIE. Metode ADDIE terdiri atas tahap analyze, design, develop, implement, dan evaluate (Effendi dan Zhuang, 2004, p93). Pada tahap analisis, instructional designer menganalisis kebutuhan karyawan akan materi. Pada tahap desain, instructional designer membuat tujuan pelatihan spesifik, merancang program pelatihan, serta mendesain isi pelajaran. Kemudian developer membuat desain menjadi paket pelajaran e- learning pada tahap pengembangan. Pada tahap penerapan, paket pelajaran disampaikan kepada anggota organisasi, kemudian pada tahap evaluasi akan dilakukan pengukuran efektivitas pelajaran.

\section{Learning Management System}

Morten Flate Paulsen (2002) dalam jurnalnya menyatakan bahwa Learning management system adalah istilah yang digunakan untuk sistem yang mengorganisasikan dan menyediakan akses ke pembelajaran online untuk siswa, guru dan administrator dengan fasilitas seperti: manajemen kelas, manajemen materi, personalisasi dan forum diskusi. Sedangkan menurut Barrit dan Alderman (2004, p233), learning management system merupakan alat atau sistem yang digunakan untuk autentifikasi, registrasi, dan akses untuk pembelajaran. Sebagian besar berisi katalog atau list materi yang tersedia dan metode bagi pembelajar untuk mendapatkan materi tersebut.

\section{Strategi E-Learning}

Menurut pakar E-Learning, Rosenberg (2006) menyatakan bahwa seringkali kita terpukau dengan kemungkinan dan kemampuan yang bisa ditawarkan oleh teknologi dan melupakan lingkungan di mana sistem itu akan diterapkan. Strategi pada organisasi dan anggota organisasi sangat penting untuk menentukan keberhasilan E-Learning yang memberikan keuntungan pada organisasi.

Tujuan strategi E-Learning adalah: (1) memperjelas tujuan pelatihan atau pendidikan yang ingin dicapai. Tujuan pelatihan atau pembelajaran harus selaras dengan tujuan organisasi. Organisasi harus bisa mencapai tujuan yang telah ditetapkan dengan menerapkan sistem E-Learning; (2) mengetahui sumberdaya yang dibutuhkan. Strategi E-Learning akan bisa memberikan gambaran pada action plan. Perumusan strategi yang lengkap akan memberikan keterangan yang sangat jelas sumber daya apa saja yang dibutuhkan, pendanaan dan infrastruktur; (3) membuat semua pihak yang terlibat untuk tetap mengacu pada tujuan yang sama. Strategi E-Learning yang baik akan membuat semua pihak yang terlibat untuk tetap mengacu pada suatu jadwal dan action plan yang sama dan konsisten; (4) mengetahui ukuran keberhasilan. Dengan strategi E-Learning, penerapan E-Learning bisa diukur tingkat keberhasilannya.

Menurut Effendi dan Zhuang (2005), tahap analisis adalah tahap awal yang harus dilakukan dan merupakan tahap yang paling penting. Analisis yang dilakukan pada strategi E-Learning tidak jauh berbeda dengan analisis SWOT. Analisis yang dilakukan di sini bisa diselaraskan dengan analisis SWOT dari organisasi tersebut. Faktor kebutuhan organisasi harus dianalisis dalam strategi ELearning. Mengapa organisasi ingin menerapkan E-Learning? Organisasi seringkali melihat suatu keuntungan yang intangible dari penerapan E-Learning. Namun, harus diperhatikan bahwa ELearning yang kemudian diterapkan akan bisa memenuhi kebutuhan organisasi. Pada penerapan $E$ Learning di sekolah, kita harus melihat apakah kebutuhan dari sekolah tersebut. Kebutuhan dari sekolah seperti peningkatan kualitas pembelajaran, penambahan metode alternatif pembelajaran harus bisa dicapai dengan adanya E-Learning. Perusahaan dapat menjalankan berbagai macam strategi. Strategi-strategi tersebut dapat diklasifikasikan ke dalam kategori seperti dalam Tabel 1 berikut: Tabel 1 


\begin{tabular}{|c|c|}
\hline Strategi & Definisi \\
\hline \multicolumn{2}{|l|}{ Integrasi } \\
\hline Integrasi ke depan & Meningkatkan kendali atas distributor \\
\hline Integrasi ke belakang & Meningkatkan kendali atas perusahaan supplier \\
\hline Integrasi horizontal & $\begin{array}{l}\text { Mengakuisisi dan mengintegrasi dengan } \\
\text { perusahaan pesaing }\end{array}$ \\
\hline \multicolumn{2}{|r|}{ 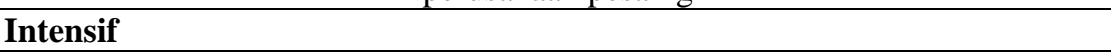 } \\
\hline Penetrasi pasar & $\begin{array}{l}\text { Meningkatkan pangsa pasar untuk produk/jasa } \\
\text { yang sudah ada dengan promosi dan pemasaran } \\
\text { yang lebih baik }\end{array}$ \\
\hline Pengembangan pasar & $\begin{array}{l}\text { Memperkenalkan produk/jasa yang sudah ada ke } \\
\text { pangsa pasar dan wilayah geografis yang berbeda }\end{array}$ \\
\hline Pengembangan produk & $\begin{array}{l}\text { Mengembangkan produk/jasa yang baru untuk } \\
\text { pangsa pasar yang sama }\end{array}$ \\
\hline \multicolumn{2}{|l|}{ Diversifikasi } \\
\hline Diversifikasi konsentrik & $\begin{array}{l}\text { Menambah produk/jasa yang masih berkaitan } \\
\text { dengan produk/jasa yang sudah ada }\end{array}$ \\
\hline Diversifikasi konglomerat & $\begin{array}{l}\text { Menambah produk/jasa yang tidak berkaitan } \\
\text { sama sekali ke pasar yang berbeda }\end{array}$ \\
\hline Diversifikasi horizontal & $\begin{array}{l}\text { Menambah produk/jasa yang tidak berkaitan } \\
\text { dengan produk/jasa yang sudah ada kepada pasar } \\
\text { yang sudah ada }\end{array}$ \\
\hline \multicolumn{2}{|l|}{ Defensif } \\
\hline Rasionalisasi Biaya & $\begin{array}{l}\text { Merestrukturisasi dengan mengurangi biaya dan } \\
\text { aset untuk meningkatkan penjualan dan } \\
\text { keuntungan }\end{array}$ \\
\hline Divestasi & $\begin{array}{l}\text { Menjual kembali divisi atau bagian perusahaan } \\
\text { dan menarik kembali investasi }\end{array}$ \\
\hline Likuidasi & $\begin{array}{l}\text { Menjual semua aset perusahaan untuk menutupi } \\
\text { kerugian perusahaan }\end{array}$ \\
\hline
\end{tabular}

Selain 12 strategi alternatif di atas, ada juga tiga strategi umum menurut David (2006, p.247): (1) cost leadership (keunggulan biaya), yaitu menekankan pada pembuatan produk dengan biaya yang rendah; (2) differentiation (differensiasi), yaitu membuat produk dan jasa yang berbeda dari pesaingpesaing yang lain; (3) focus (fokus), yaitu membuat produk dan jasa yang dispesialisasikan kepada segmen kelompok tertentu.

\section{Analisis Internal dan Eksternal Organisasi}

Tahap Masukan (Input Stage) - Perangkat-perangkat masukan membantu penulisan penilaian dan asumsi kuantitatif untuk awal proses perumusan strategi. David (2006, p.283) menyatakan bahwa informasi dari matriks EFE , IFE dan CPM menjadi informasi masukan untuk tahap pencocokan. Matriks EFE (External Factor Evaluation) memberikan fasilitas evaluasi informasi eksternal perusahaan seperti ekonomi, sosial-budaya, demografi, lingkungan, hukum dan teknologi. Sedangkan matriks IFE (Internal Factor Evaluation) merupakan perangkat yang mengevaluasi kekuatan dan kelemahan utama dalam organisasi.

Tahap Pencocokan (Matching Stage) - ada lima teknik yang dapat dipakai tanpa harus berurutan untuk tahap pencocokan dari kerangka perumusan strategi. Perangkat ini bergantung pada informasi yang diperoleh dari tahap masukan untuk mencocokan peluang dan ancaman eksternal dengan kekuatan dan kelemahan internal perusahaan. Salah satu tekniknya adalah SWOT Matrix (Threats - Opportunities - Weaknesses - Strengths). Menurut David (2006, p.204) matrix SWOT ini 
dengan menggunakan ADDIE, dan terakhir analisis sistem dengan melihat sistem yang sedang berjalan di perusahaan, serta digambarkan dengan rich picture sistem berjalan, serta melakukan gap analysis. Terakhir untuk perancangan sistemnya menggunakan metode OOAD yang terdiri atas rich picture, factor, class diagram, use case, sequence diagram, dan navigation diagram. Gambar 1 berikut ini adalah kerangka berpikirnya.

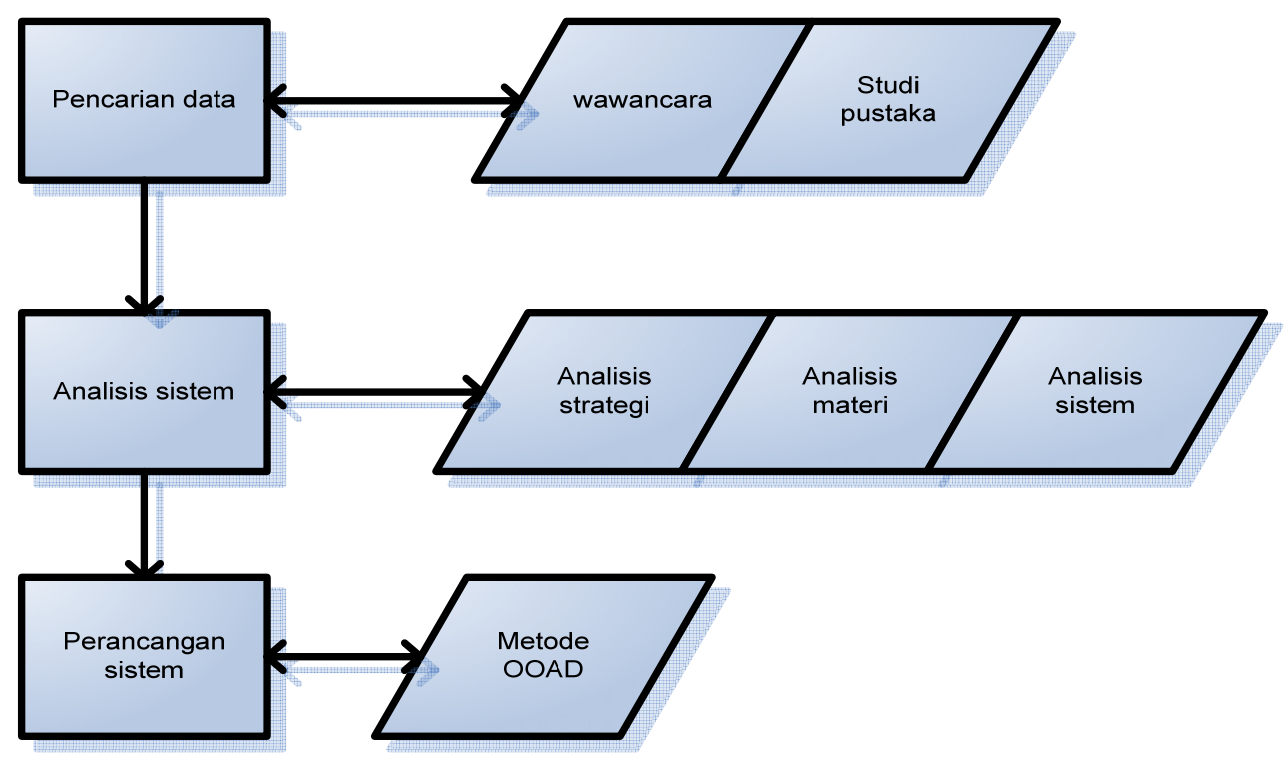

Gambar 1. Kerangka berpikir.

\section{Analisis Kebutuhan Sistem E-Learning}

\section{Analisis Strategi}

Berdasarkan data- data yang telah ditemukan, dapat dibuat matriks EFE dan IFE, selanjutnya dibuat matriks SWOT dan IE untuk mencocokkan strategi, lalu untuk tahap terakhir digunakan matriks QSPM (Tabel 3) untuk menentukan strategi yang paling tepat untuk diterapkan organisasi.

Tabel 3

Matriks QSPM

\begin{tabular}{lllllll}
\hline & & \multicolumn{4}{c}{ Pengembangan } \\
& & \multicolumn{3}{c}{ Penetrasi Pasar } & \multicolumn{2}{c}{ Pasar } \\
\hline No Faktor Eksternal & Bobot & AS & TAS & AS & TAS \\
\hline Peluang (Opportunities) & & & & & & \\
\hline
\end{tabular}

\begin{tabular}{|c|c|c|c|c|c|c|}
\hline 1 & Pertumbuhan ekonomi yang meningkat & 0.130 & - & - & - & - \\
\hline 2 & $\begin{array}{l}\text { Banyaknya masalah sosial yang belum } \\
\text { teratasi sepenuhnya di Indonesia }\end{array}$ & 0.266 & 2 & 0.532 & 3 & 0.798 \\
\hline 3 & $\begin{array}{l}\text { Banyaknya LSM dan organisasi sosial } \\
\text { lainnya }\end{array}$ & 0.073 & 4 & 0.292 & 2 & 0.146 \\
\hline 4 & $\begin{array}{l}\text { Banyaknya bencana alam yang terjadi di } \\
\text { Indonesia }\end{array}$ & 0.083 & 3 & 0.249 & 1 & 0.083 \\
\hline 5 & $\begin{array}{l}\text { Sikap solidaritas dan kemanusiaan } \\
\text { masyarakat Indonesia }\end{array}$ & 0.183 & - & - & - & - \\
\hline
\end{tabular}

ancaman (threats) 


\begin{tabular}{|c|c|c|c|c|c|c|}
\hline 6 & $\begin{array}{l}\text { Pandangan masyarakat akan identitas } \\
\text { organisasi }\end{array}$ & 0.053 & 4 & 0.212 & 1 & 0.053 \\
\hline 7 & Munculnya kompetitor baru & 0.052 & 4 & 0.208 & 2 & 0.104 \\
\hline 8 & $\begin{array}{l}\text { Kondisi infrastruktur transportasi di } \\
\text { Indonesia }\end{array}$ & 0.039 & 2 & 0.078 & 1 & 0.039 \\
\hline 9 & Peraturan pemerintah yang tidak mendukung & 0.064 & 2 & 0.128 & 1 & 0.064 \\
\hline 10 & Terjadinya resesi ekonomi di negara maju & 0.057 & 4 & 0.228 & 2 & 0.114 \\
\hline \multicolumn{7}{|c|}{ Kekuatan (strength) } \\
\hline 1 & $\begin{array}{l}\text { Teknologi yang dimiliki oleh World Vision } \\
\text { Indonesia }\end{array}$ & 0.135 & 2 & 0.27 & 4 & 0.54 \\
\hline 2 & Karyawan yang komitmen & 0.087 & 2 & 0.174 & 3 & 0.261 \\
\hline 3 & $\begin{array}{l}\text { Hubungan yang baik dengan pihak } \\
\text { pemerintah Indonesia }\end{array}$ & 0.137 & - & - & - & - \\
\hline 4 & $\begin{array}{l}\text { Budaya organisasi yang mendukung } \\
\text { terciptanya organisasi pembelajaran }\end{array}$ & 0.174 & 1 & 0.174 & 4 & 0.696 \\
\hline 5 & $\begin{array}{l}\text { Memiliki pengukuran yang jelas terhadap } \\
\text { performa manajemen }\end{array}$ & 0.038 & - & - & - & - \\
\hline \multicolumn{7}{|c|}{ kelemahan (weakness) } \\
\hline 1 & $\begin{array}{l}\text { Dukungan finansial yang berasal dari pihak } \\
\text { luar }\end{array}$ & 0.068 & 4 & 0.272 & 3 & 0.204 \\
\hline 2 & Mobilisasi karyawan sulit & 0.057 & 1 & 0.057 & 2 & 0.114 \\
\hline 3 & Mahalnya biaya pelatihan & 0.135 & 1 & 0.135 & 4 & 0.54 \\
\hline 4 & $\begin{array}{l}\text { Wadah untuk menyimpan pengetahuan } \\
\text { masih belum ada }\end{array}$ & 0.051 & 1 & 0.051 & 4 & 0.204 \\
\hline \multirow[t]{2}{*}{5} & $\begin{array}{l}\text { Image perusahaan belum terlalu dikenal } \\
\text { masyarakat }\end{array}$ & 0.118 & 4 & 0.472 & 1 & 0.118 \\
\hline & & & & 3.532 & & 4.078 \\
\hline
\end{tabular}

Dari hasil QSPM, strategi yang sebaiknya dilakukan oleh organisasi adalah dengan strategi pengembangan pasar dengan melakukan transformasi pelatihan dengan penerapan learning management system karena memiliki nilai yang lebih besar dari strategi penetrasi pasar, serta sesuai dengan kebutuhan organisasi akan pelatihan yang lebih efektif dan efisien. Strategi transformasi pelatihan ini akan mengurangi biaya pelatihan organisasi World Vision Indonesia, serta dapat menjadi suatu wadah untuk penyimpanan dan pertukaran informasi ataupun pengetahuan di dalam perusahaan. Penerapan LMS ini juga sangat ditunjang oleh teknologi yang telah dimiliki oleh organisasi serta adanya budaya pembelajaran yang didukung oleh pihak manajemen.

\section{Analisis Sistem Berjalan}

World Vision Indonesia memiliki tiga jenis pelatihan utama dalam organisasinya yang berupa pelatihan orientasi untuk karyawan baru yang akan dilakukan kurang lebih dua kali setahun, pelatihan I- Learn yang mengumpulkan seluruh karyawan World Vision Indonesia yang tersebar di berbagai kantor proyek untuk berkumpul di Jakarta, serta pelatihan teknikal untuk meningkatkan kemampuan karyawan sesuai dengan bagian operasionalnya. Rich picture yang menggambarkan sistem pelatihan yang berjalan di World Vision Indonesia secara keseluruhan adalah sebagai berikut (Gambar 2): 


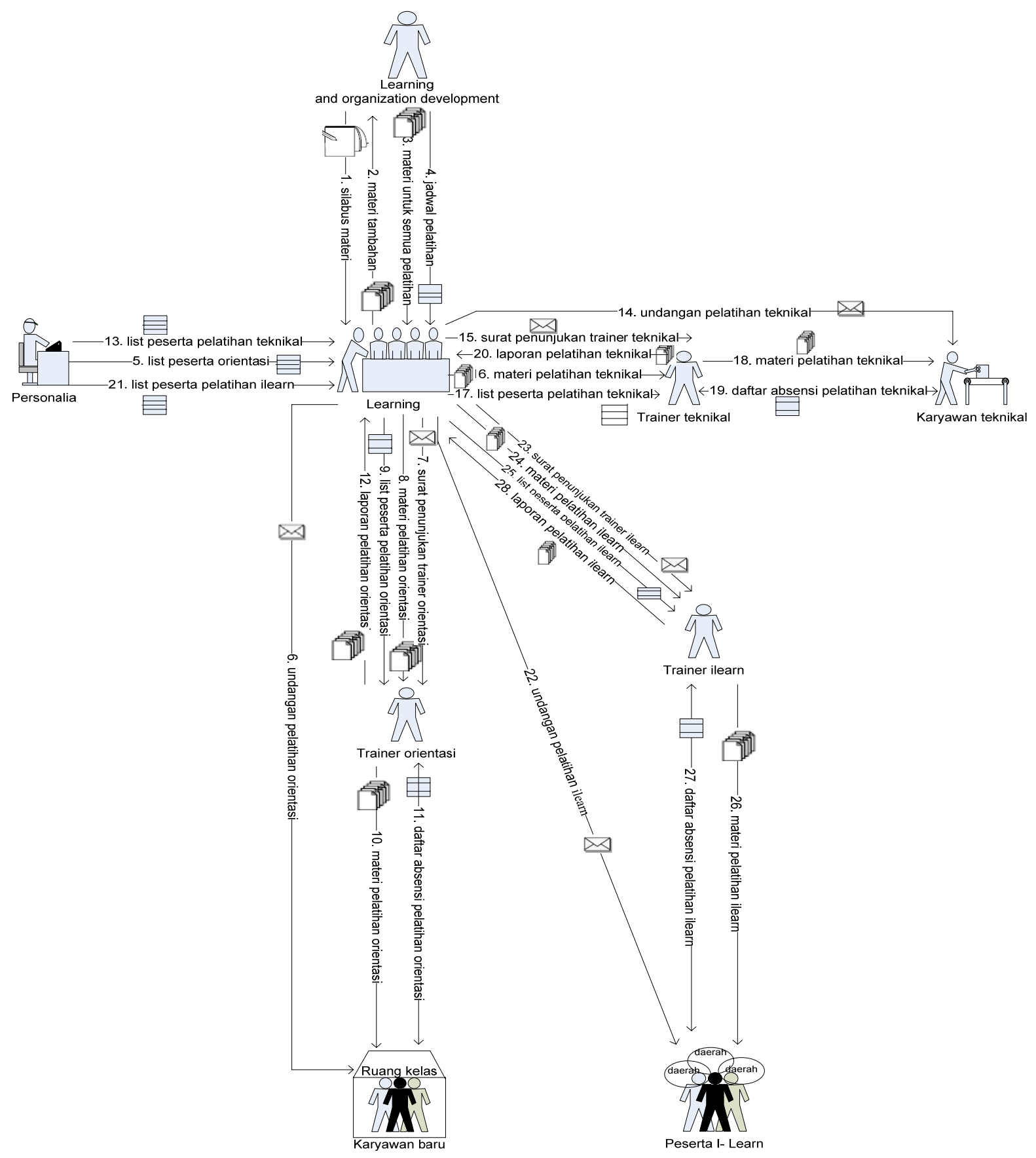

Gambar 2. Rich Picture yang sedang berjalan.

Pelaksanaan masing-masing pelatihan akan digambarkan secara lebih rinci dengan rich picture berikut (Gambar $3-5)$ : 


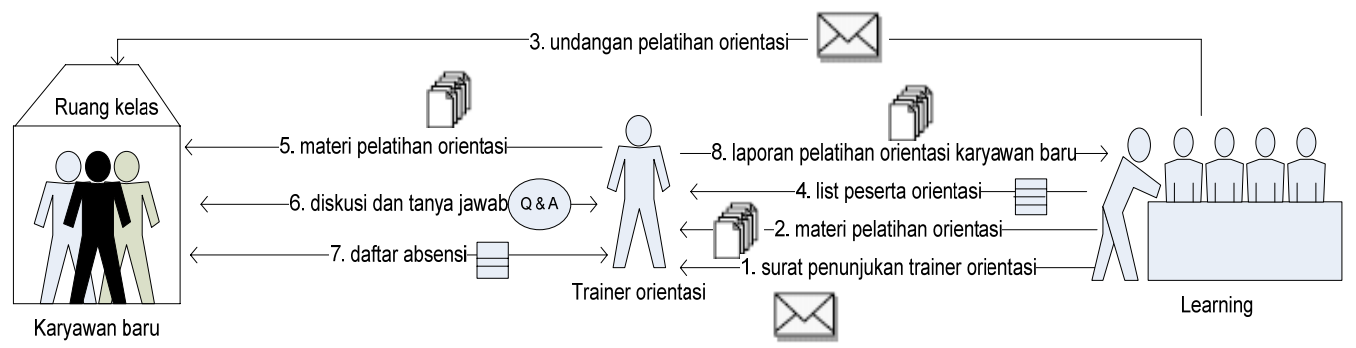

Gambar 3. Rich picture sedang berjalan khusus orientasi.

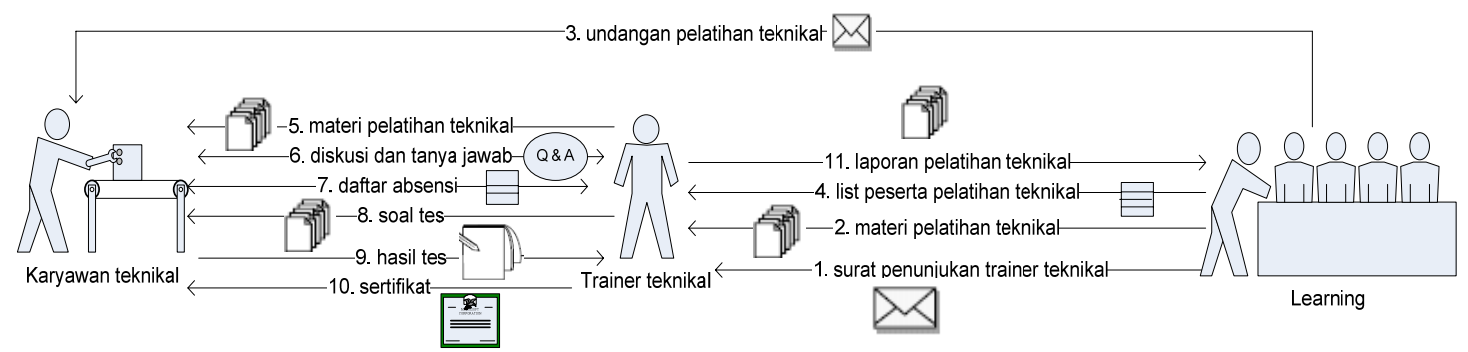

Gambar 4. Rich picture sedang berjalan khusus teknikal.

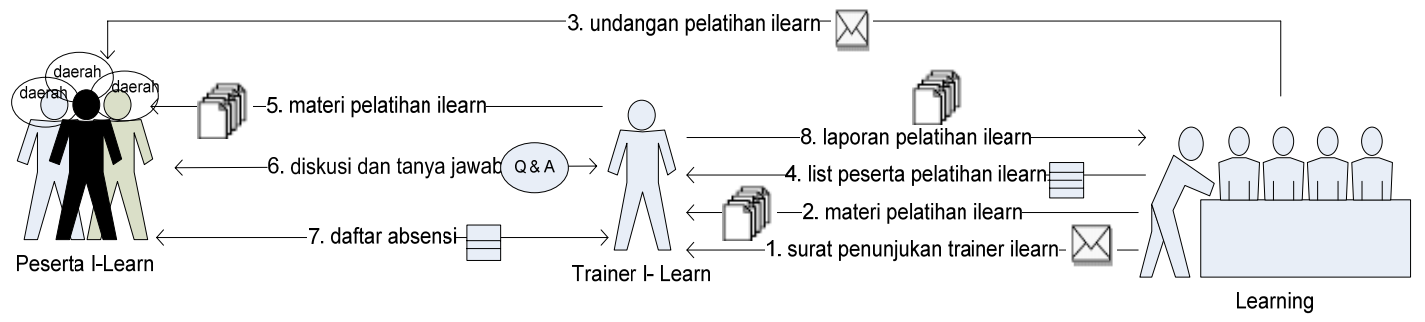

Gambar 5. Rich picture sedang berjalan khusus I- Learn.

\section{Analisis Perbedaan (Gap Analysis)}

Dari hasil perbedaan antara kinerja yang dimiliki oleh karyawan sekarang ini dengan kinerja yang diinginkan oleh pihak manajemen, maka dapat diketahui penyebab perbedaan tersebut. Berikut ini merupakan gambar analisis gap (Gambar 6):

\section{Analisis Kebutuhan Materi}

Analisis kebutuhan materi ini merupakan bagian dari tahap analisis dalam metode ADDIE. Dari data dan hasil wawancara dari pihak manajemen dan karyawan World Vision Indonesia, diperoleh daftar kompetensi yang diharapkan dimiliki oleh karyawan World Vision Indonesia. Kompetensi tersebut dibagi menjadi empat jenis, yaitu: (1) kompetensi wajib atau kompetensi inti, merupakan kompetensi yang diperlukan pada semua jabatan di WVI untuk dapat menghasilkan kinerja yang efektif dan efisien. Kompetensi wajib adalah turunan atau nilai- nilai yang wajib dimiliki untuk mencapai tujuan pendirian organisasi atau mewujudkan visi, misi, filosofi, dan nilai WVI. Contoh kompetensi wajib ini berupa semangat untuk berprestasi, integritas, empati, komitmen terhadap organisasi, berpikir analitis, berpikir konseptual, dan fleksibel; (2) kompetensi pendukung, adalah kompetensi yang diperlukan jabatan tertentu di WVI agar mampu menghasilkan kinerja yang efektif 
dan efisien. Contoh kompetensi pendukung adalah perhatian terhadap kejelasan tugas, kualitas, dan ketelitian kerja, proaktif, mencari informasi, memimpin kelompok, kerjasama kelompok, percaya diri, dan lainnya; (3) kompetensi bidang adalah kompetensi- kompetensi dalam bentuk pengetahuan dan ketrampilan yang diperlukan pada suatu jabatan berdasarkan aktivitas- aktivitas kunci yang harus dilakukan pada jabatan tersebut. Contoh kompetensi bidang adalah kompetensi bidang keuangan (dapat berupa akuntansi keuangan, manajemen keuangan, dan perpajakan), kompetensi bidang Sumber daya manusia (berupa perencanaan SDM, manajemen karir, dan pelatihan SDM), kompetensi bidang umum (dapat berupa kemampuan bahasa inggris, kemampuan menulis dengan baik, pengelolaan program- program organisasi, dan pengetahuan mengenai bidang sosial tempat perusahaan melakukan operasionalnya); (4) kompetensi khusus, adalah kompetensi- kompetensi khusus dalam bentuk pengetahuan dan keterampilan yang dibutuhkan pada suatu jabatan berdasarkan aktivitas- aktivitas kunci yang harus dilakukan pada jabatan. Contohnya adalah keterampilan pengembangan spiritual, pemahaman identitas organisasi, nilai- nilai Kristen, dan lainnya.

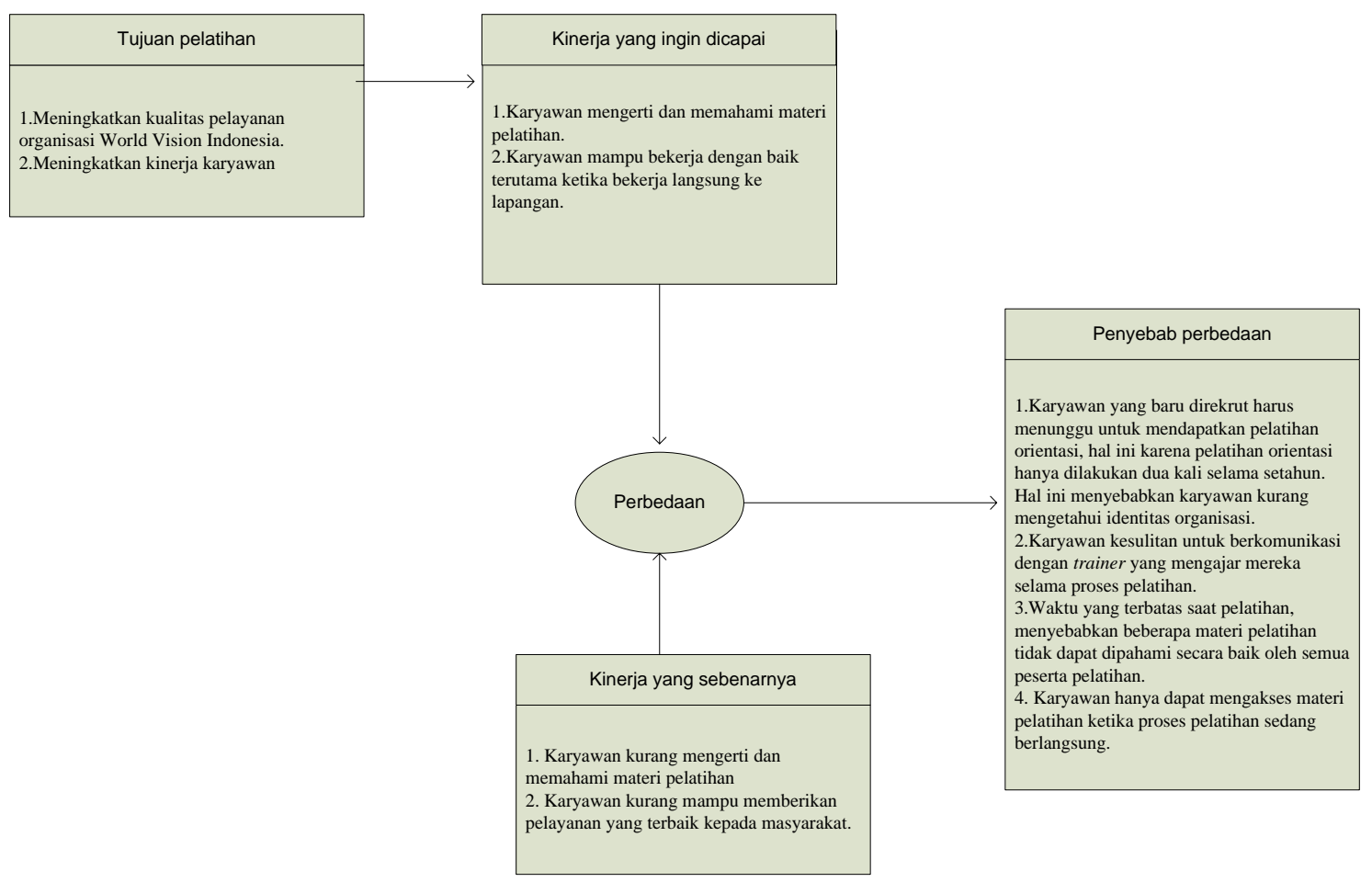

Gambar 6. Hasil analisis gap.

Selain itu diketahui bahwa materi utama yang dibutuhkan World Vision Indonesia adalah informasi mengenai identitas organisasi World Vision (bagian kompetensi khusus), serta informasi tambahan mengenai kesehatan, pendidikan, dan ekonomi (bagian kompetensi bidang). Informasi mengenai identitas organisasi sangat penting untuk dipahami dan dimengerti oleh seluruh karyawan World vision Indonesia agar mereka dapat bekerja sesuai dengan visi dan misi organisasi, sedangkan informasi mengenai kesehatan, pendidikan, dan ekonomi dibutuhkan oleh staff yang bekerja langsung dilapangan. Selanjutnya dari hasil kompetensi dan kebutuhan tersebut akan menjadi materi dalam LMS. Misalnya untuk kebutuhan kompetensi bidang keuangan, terdapat materi mengenai manajemen keuangan. Sedangkan hubungan antara pelatihan dan kompetensi adalah sebagai berikut: (1) pelatihan I- Learn, mempelajari kompetensi wajib dan kompetensi pendukung; (2) pelatihan orientasi karyawan baru, mempelajari kompetensi wajib dan kompetensi khusus; (3) pelatihan operasional atau teknikal, mempelajari kompetensi bidang 


\section{Perancangan}

\section{Perancangan Materi}

Bagian ini merupakan bagian dari metode ADDIE, yang digunakan untuk penyusunan materi pelatihan. Berdasarkan hasil dari analisis kebutuhan materi yang membagi kebutuhan pelatihan menjadi empat kompetensi utama, seperti kompetensi wajib, kompetensi pendukung, kompetensi bidang, dan kompetensi khusus maka perancangan materi atau content akan berdasarkan kompetensi tersebut. Keempat kompetensi utama tersebut akan digambarkan dengan beberapa kompetensi spesifik. Kompetensi-kompetensi spesifik ini antara lain adalah sebagai berikut:

Pertama, semangat untuk berprestasi, merupakan salah satu kompetensi yang terdapat dalam kompetensi wajib. Materi dari kompetensi semangat untuk berprestasi tidak terdapat dalam materi yang disediakan dalam LMS, karena kompetensi semangat untuk berprestasi bukanlah suatu materi yang dapat diperoleh dengan hanya membaca suatu materi tertentu. Materi- materi tersebut akan lebih mudah dipahami atau dimengerti jika dilakukan atau dipraktekkan secara langsung ketika sedang bekerja. Jadi untuk materi yang berupa kompetensi wajib ini tidak terdapat dalam LMS, karena inti pembelajaran materi kompetensi wajib ini akan ditemukan saat sedang mengerjakan suatu pekerjaan. Lama sesi atau waktu pembelajaran untuk kompetensi wajib ini tidak ditentukan karena proses pembelajarannya adalah secara terus- menerus selama sedang beraktivitas. Tujuan dari kompetensi wajib ini adalah meningkatkan kemampuan staff untuk menghadapi masalah dalam pekerjaannya.

Kedua, percaya diri, merupakan salah satu kompetensi yang terdapat dalam kompetensi pendukung. Materi dari kompetensi percaya diri akan terdapat dalam materi yang disediakan dalam LMS. Bentuk materi dari kompetensi ini akan disediakan dalam bentuk slide presentasi atau slide power point yang akan menjelaskan pentingnya rasa percaya diri, dan langkah-langkah untuk menumbuhkan rasa percaya diri. Jadi untuk materi yang berupa kompetensi pendukung akan disediakan oleh LMS dalam bentuk slide power point. Lama sesi atau waktu pembelajaran untuk kompetensi pendukung ini ditentukan besarnya waktu yang dibutuhkan untuk memahami materi. Namun untuk perkiraan awal, penulis menargetkan terdapat tiga sesi untuk masing- masing kompetensi pendukung ini, dimana waktu untuk setiap sesi adalah sekitar 40 menit. Tujuan dari kompetensi wajib ini adalah meningkatkan kemampuan atau kompetensi staff World Vision Indonesia sehingga mampu bekerja dengan efisien dan efektif. Metode belajarnya dalam LMS adalah menyediakan studi kasus terlebih dahulu agar peserta menjadi tertarik untuk melanjutkan proses pelatihan.

Ketiga, manajemen keuangan, merupakan salah satu kompetensi yang terdapat dalam kompetensi bidang. Materi dari kompetensi manajemen keuangan akan terdapat dalam materi yang disediakan dalam LMS. Bentuk materi dari kompetensi ini akan disediakan dalam bentuk slide presentasi atau slide power point yang akan menjelaskan pengertian dari manajemen keuangan, penjelasan rumus-rumus dalam manajemen keuangan dan langkah- langkah untuk memecahkan perhitungan manajemen keuangan. Jadi untuk materi yang berupa kompetensi pendukung akan disediakan oleh LMS dalam bentuk slide power point. Lama sesi atau waktu pembelajaran untuk kompetensi bidang ini sangat bervariasi ditentukan oleh tingkat kesukaran masing- masing kompetensi. Namun untuk perkiraan awal, ditargetkan terdapat lima sesi untuk masing- masing kompetensi bidang ini, dimana waktu untuk setiap sesi adalah sekitar 75 menit. Sebagai contoh sesi untuk manajemen keuangan akan terbagi menjadi lima sesi. Dimana sesi pertama akan mempelajari pengertian manajemen keuangan, dan teori- teori pendukungnya. Sesi kedua akan menjelaskan perhitungan niainilai intrinsik dan entrinsik dimasa yang akan datang, sesi ketiga menjelaskan perhitungan net present value, present value. Sesi keempat memberikan contoh- contoh penyelesaian masalah perhitungan NPV, dan sesi kelima memberikan pengetahuan cara- cara mengelola keuangan. Tujuan dari kompetensi bidang ini adalah meningkatkan kemampuan atau kompetensi staff World Vision 
Indonesia dalam bidang yang sesuai dengan pekerjaan staff tersebut sehingga mereka mampu bekerja dengan baik. Metode belajarnya dalam lms adalah menyediakan materi pelatihan yang dapat di download yang akan mendukung proses pelatihan secara fisik.

Keempat, pemahaman identitas dan pelayanan organisasi, merupakan salah satu kompetensi yang terdapat dalam kompetensi khusus. Materi dari kompetensi pemahaman identitas dan pelayanan organisasi akan terdapat dalam materi yang disediakan dalam LMS. Bentuk materi dari kompetensi ini akan disediakan dalam bentuk slide presentasi atau slide power point yang akan menjelaskan identitas organisasi dan pelayanan yang diberikan organisasi. Jadi untuk materi yang berupa kompetensi khusus akan disediakan oleh LMS dalam bentuk teks, ataupun power point. Lama sesi atau waktu pembelajaran untuk kompetensi khusus ini adalah selama satu sesi, dimana waktu untuk setiap sesi adalah sekitar 30 menit. Tujuan dari kompetensi khusus ini adalah meningkatkan pengetahuan dan pemahaman staff World Vision Indonesia mengenai pekerjaan dan identitas dari organisasi World Vision. Metode belajarnya dalam Ims adalah memberikan pertanyaan terlebih dahulu ke pada peserta pelatihan agar mereka menyadari tingkat pengetahuan mereka, dan memunculkan rasa keingintahuan yang lebih besar mengenai materi dalam kompetensi ini.

Pengembangan materi atau content dari keempat contoh kompetensi spesifik tersebut adalah: (1) semangat untuk berprestasi, yang sebelumnya hanya akan didapatkan oleh karyawan ketika sedang mengerjakan suatu aktivitas tertentu, untuk kedepannya akan diadakan seminar baik mingguan ataupun bulanan yang diharapkan dapat membuat staff World Vision semakin bersemangat; (2) percaya diri, materi ini sebelumnya hanya disampaikan lewat slide presentasi atau power point sedangkan untuk kedepannya akan tetap diberikan lewat slide presentasi ditambah dengan adanya video ataupun audio yang dapat membangkitkan rasa percaya diri staff World Vision Indonesia dalam mengerjakan pekerjaannya; (3) manajemen keuangan, materi ini sebelumnya hanya disampaikan lewat slide presentasi sedangkan untuk kedepannya akan tetap diberikan lewat slide presentasi ditambah dengan adanya simulai perhitungan yang dapat meningkatkan pengetahuan staff World Vision Indonesia mengenai perhitungan dalam kompetensi bidang manajemen keuangan; (4) pemahaman identitas dan pelayanan organisasi, materi ini sebelumnya hanya disampaikan lewat slide presentasi sedangkan untuk kedepannya akan tetap diberikan lewat slide presentasi ditambah dengan penginformasian secara lebih terbuka mengenai identitas dan pelayanan organisasi melalui papan pengumuman yang dapat meningkatkan pemahaman staff World Vision Indonesia mengenai identitas dari organisasi World Vision.

Tahap implementasi materi dalam Learning Management System akan dibagi dalam lima tahap utama beserta dengan jangka waktu pelaksanaan dari masing-masing tahap tersebut. Tahap pertama merupakan kegiatan menganalisis kebutuhan pelatihan dengan waktu pelaksanaanya adalah dua minggu; tahap kedua adalah kegiatan merancang materi pelatihan dengan waktu pelaksanaannya adalah dua minggu; tahap ketiga adalah kegiatan mengembangkan materi pelatihan dengan waktu pelaksanaannya adalah satu minggu; tahap keempat adalah kegiatan melaksanakan pelatihan dengan waktu pelaksanaannya adalah dua minggu; serta tahap kelima adalah kegiatan mengevaluasi hasil pelatihan dengan waktu pelaksanaannya adalah satu minggu. Untuk lebih jelasnya dapat melihat gantt charts berikut ini:

Tabel 4

Gantt Chart Implementasi Materi Pelatihan

\begin{tabular}{llllllllll}
\hline No & Kegiatan & \multicolumn{1}{c}{ Waktu (Minggu) } \\
\hline & & 1 & 2 & 3 & 4 & 5 & 6 & 7 & 8 \\
\hline 1 & Menganalisis kebutuhan pelatihan & & & & & & & & \\
\hline 2 & Merancang materi pelatihan & & & & & & & & \\
\hline 3 & Mengembangkan materi pelatihan & & & & & & & \\
\hline
\end{tabular}


$4 \quad$ Melaksanakan pelatihan

5 Mengevaluasi hasil pelatihan

Selanjutnya, tahap evaluasi materi dalam Learning Management System dapat dibagi menjadi dua hal utama, yang berupa evaluasi dari kepuasaan karyawan atas materi- materi yang telah disediakan untuk pelatihan dan evaluasi dalam penilaian kinerja karyawan tersebut. Untuk evaluasi mengenai kepuasan karyawan atas materi yang disediakan selama pelatihan, karyawan akan diminta untuk mengisi kuisoner yang akan menanyakan tanggapan karyawan mengenai materi-materi dari pelatihan yang dilaksanakan oleh World Vision Indonesia, sedangkan untuk evaluasi dalam penilaian kinerja karyawan maka organisasi akan langsung melihat indeks performa masing-masing karyawan saat melaksanakan pekerjaannya. Dari hasil kuisoner evaluasi kepuasaan karyawan atas materi pelatihan, organisasi dapat mengembangkan isi materi ataupun mengubah cara menyampaikan materi tersebut agar mampu meningkatkan kepuasan pelanggan dalam mempelajari materi tersebut. Sedangkan dari hasil indeks performa masing- masing karyawan dapat diketahui apakah materi yang tersedia dalam pelatihan telah mampu menambah pengetahuan karyawan sehingga karyawan dapat melaksanakan tugasnya dengan baik.

\section{Perancangan Sistem}

Proses sistem pelatihan yang akan berjalan setelah penerapan aplikasi learning management system adalah sesuai dengan Gambar 7 - 10, di mana aplikasi learning management system memfasilitasi download materi pelatihan, pengerjaan soal secara online khususnya utuk pelatihan teknikal, serta forum diskusi yang mendukung komunikasi antara trainer dan trainee di luar waktu pelatihan. Berikut ini adalah gambaran usecase diagram untuk perancangan sistem LMS pada World Vision Indonesia (Gambar 11). Dalam implementasi sistem tersebut diperlukan spesifikasi software dan hardware sebagai berikut: Spesifikasi software: Kebutuhan software minimum untuk learning management system ini adalah: (1) untuk server: operating system Windows XP, Apache, Mysql, Moodle, Browser Mozilla firefox, Internet explorer, opera, Google chrome, Microsoft Office, dan Macromedia flash player; (2) untuk client: Windows XP, Browser Mozilla Firefox, Internet explorer, Opera, Google chrome; Microsoft office; Macromedia flash player. Spesifikasi hardware:Kebutuhan hardware minimum untuk learning management system ini adalah: (1) untuk server: Pentium IV, memory 1 GB, Harddisk 160 GB; (2) untuk client: Pentium IV, Memory 256 MB, Harddisk 40 GB. 


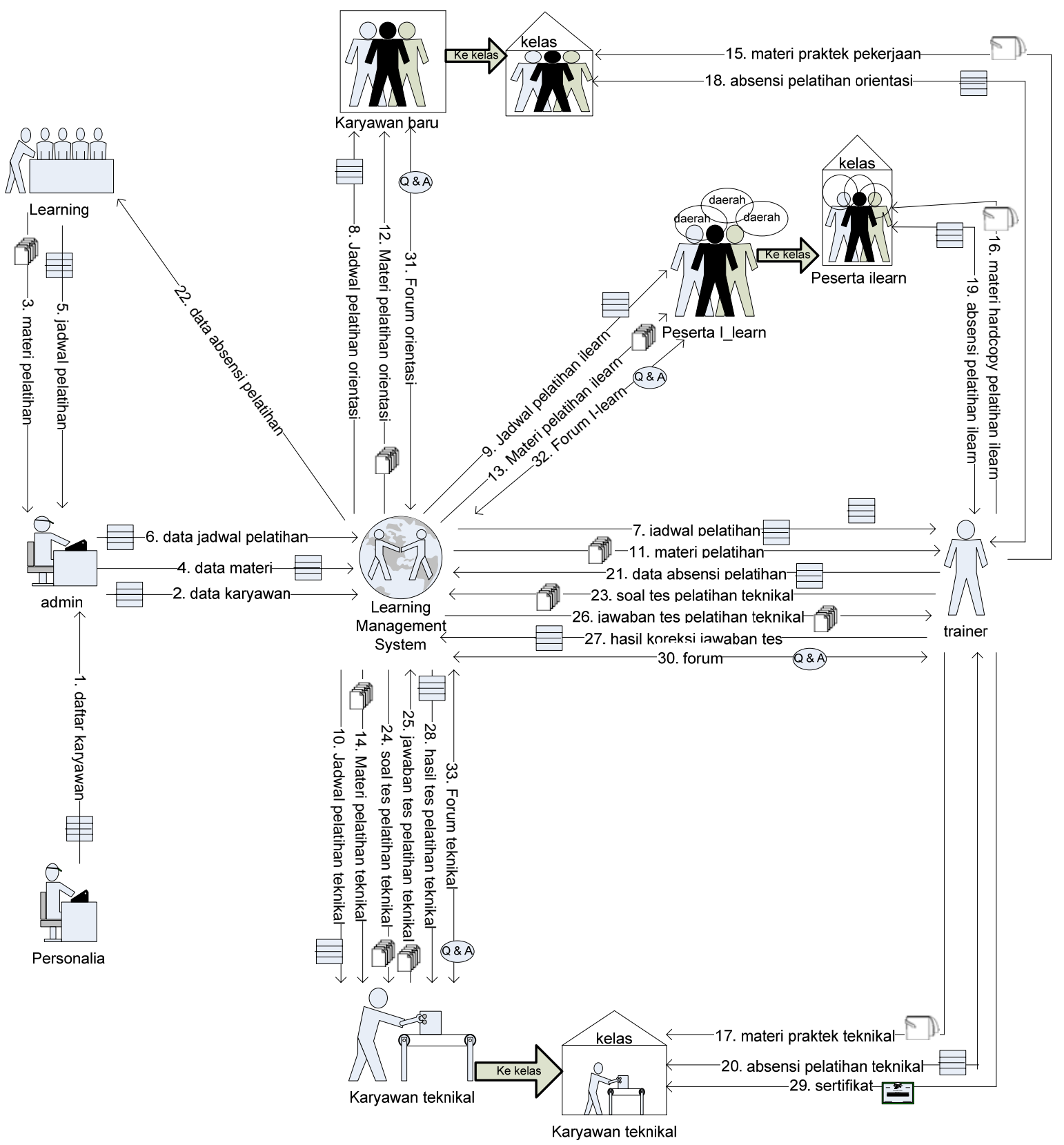

Gambar 7. Rich picture umum yang diusulkan. 


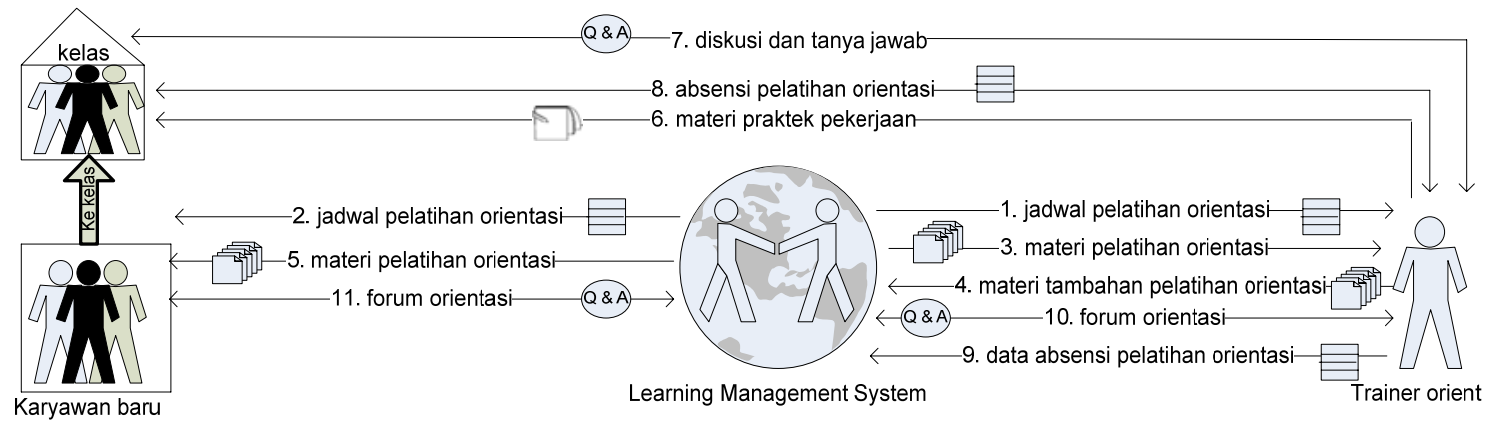

Gambar 8. Rich picture pelatihan orientasi yang diusulkan.

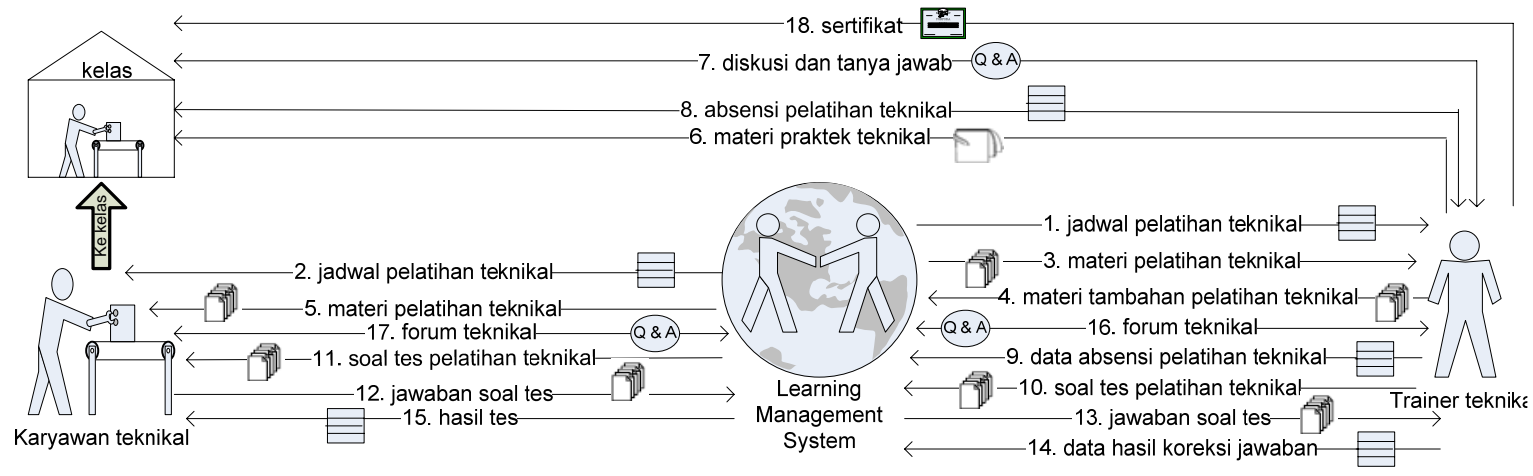

Gambar 9. Rich picture pelatihan teknikal yang diusulkan.

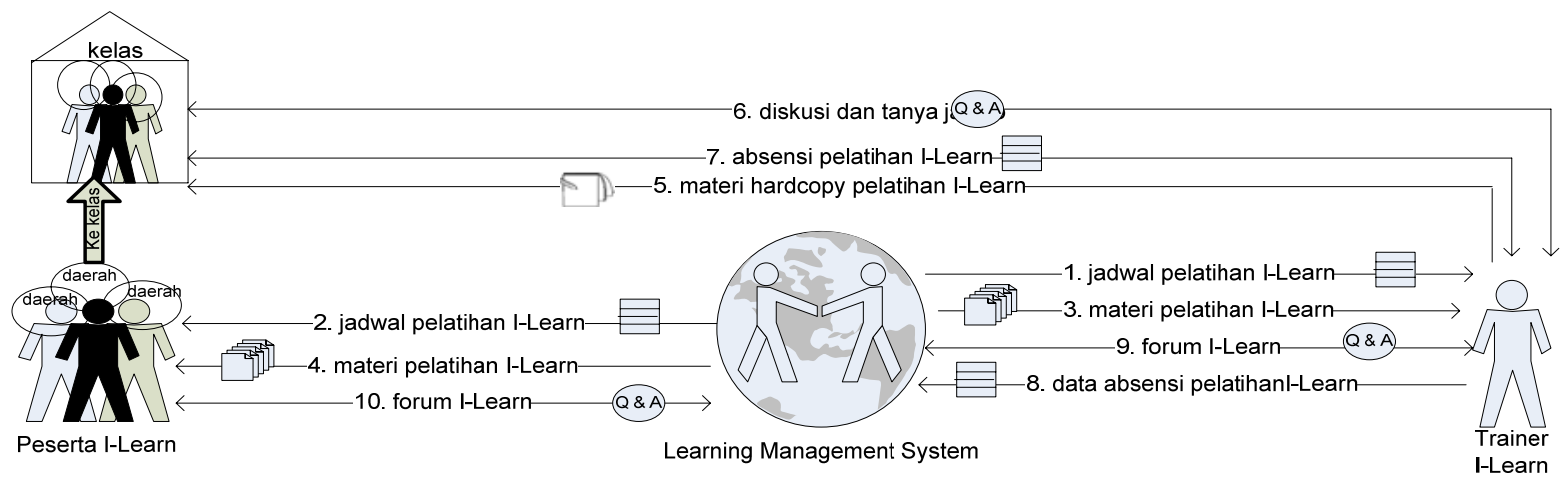

Gambar 10. Rich picture pelatihan i- learn yang diusulkan. 


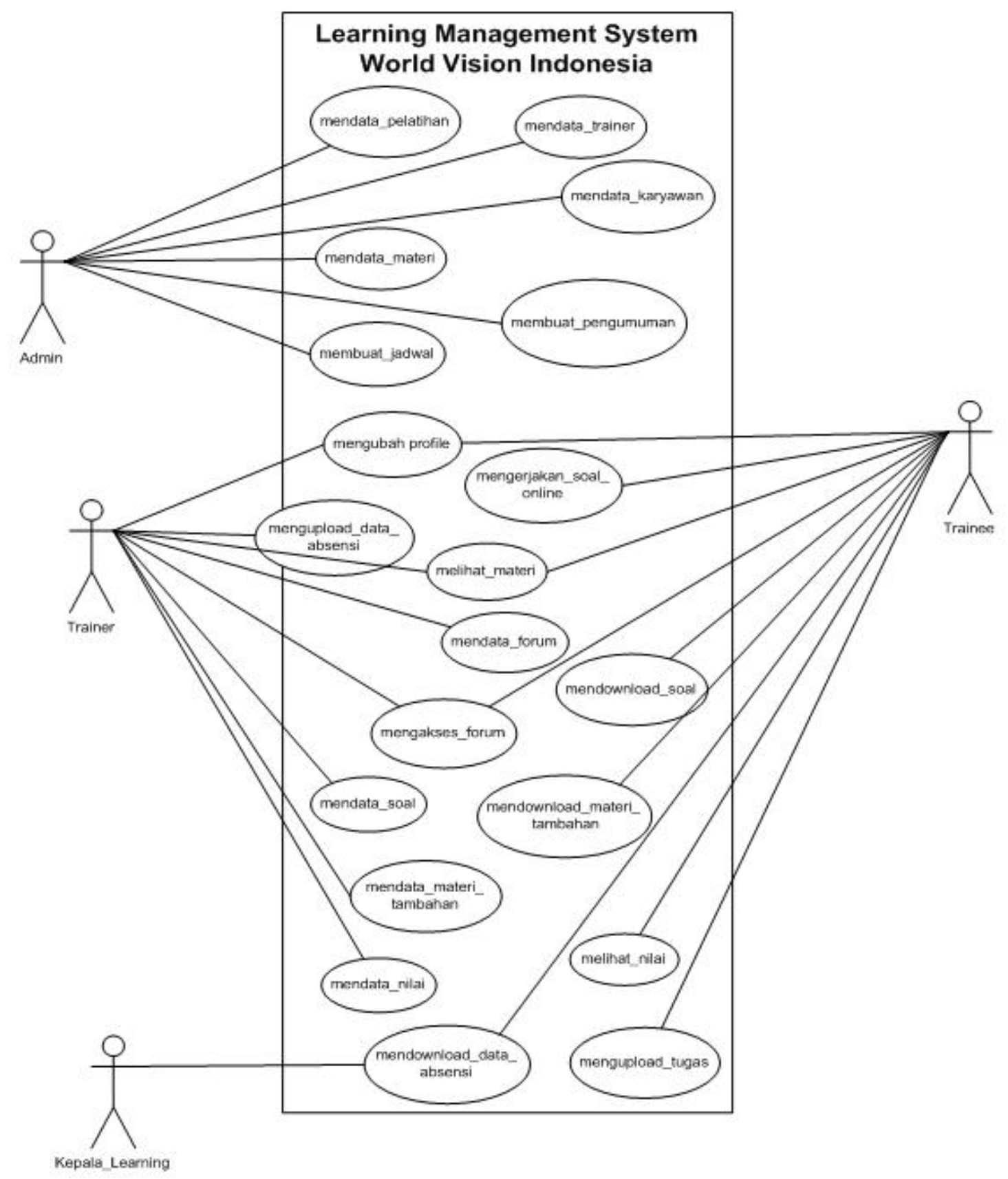

Gambar 11. Usecase diagram.

\section{PENUTUP}

Berdasarkan hasil analisis pada organisasi World Vision Indonesia dapat disimpulkan berbagai hal, antara lain: (1) melalui wawancara dapat disimpulkan bahwa pihak manajemen organisasi menginginkan penggunaan teknologi untuk mendukung proses pelatihan yang ada saat ini; (2) melalui hasil analisis strategi dimulai dari matriks IE, SWOT, sampai QSPM dapat diketahui bahwa strategi untuk mengembangkan learning management system pada organisasi dapat membawa hasil yang baik bagi organisasi; (3) learning management system menyediakan fasilitas forum, yang akan mendukung 
komunikasi antara trainer dengan trainee, serta menyediakan fasilitas download materi sebelum dimulainya proses pelatihan secara fisik. Kedua fitur tadi akan mendukung proses pelatihan yang sedang berjalan di organisasi.

Beberapa saran yang dapat penulis berikan kepada World Vision Indonesia adalah: (1) untuk pengembangan materi dalam learning management system sebaiknya dikembangkan bersama dengan trainer, sehingga trainer mengetahui dengan pasti mana materi yang harus di titikberatkan dan mana yang tidak terlalu penting; (2) dalam mengaplikasikan learning management system dibutuhkan keaktifan semua pihak, agar Learning management system dapat berjalan sesuai dengan tujuan dan keinginan semua pihak; (3) diperlukan implementasi dan evaluasi untuk menyempurnakan Learning management system; (4) pengembangan lanjutan dari LMS sebaiknya dengan penyediaan akses LMS secara mobile. Hal ini untuk mendukung strategi tumbuh dan berkembang organisasi. Dengan strategi tumbuh dan berkembang, organisasi akan mengirim karyawannya di berbagai daerah di Indonesia, dan karyawan tersebut memerlukan penyampaian materi pelatihan secara cepat dan fleksibel.

\section{DAFTAR PUSTAKA}

David, Fred R. (2006). Strategic Management: Manajemen Strategis Konsep, (ed. 10). Jakarta: Salemba Empat.

Effendi, Empy \& Zhuang, Hartono. (2005) . E-learning: Konsep dan Aplikasi. (ed. 1). Yogyakarta: Andi Offset,.

Mathiassen, L., Munk-Madsen, A., Nielsen, P. A., \& Stage, J. (2000). Object- Oriented Analysis and Design. Aalborg, Denmark: Marko Publishing Aps.

Paulsen, Morten Flate. (2002). Definition - LMS and LCMS. Diakses 24 Januari 2010 dari http://www.nettskolen.com/forskning/Definition\%20of\%20Terms.pdf.

Rosenberg, Marc.J. (2006). Beyond E-Learning: Approaches and Technologies to enhance Organizational knowledge, learning and performance. San Francisco: Pfeiffer.

Ruth, Stephen. (2010). Is E-Learning Really Working? The Trillion-DollarQuestion. IEEE Internet $\begin{array}{lllll}\text { Computing. } & \text { Diakses } & 28 & \text { November } & 2010\end{array}$ http://proquest.umi.com/pqdweb?index $=25 \&$ did $=1977595321 \&$ SrchMode $=1 \&$ sid $=1 \&$ Fmt $=2$ \&VInst=PROD\&VType=PQD\&RQT=309\&VName=PQD\&TS=1290947966\&clientId=6884.

Thompson Jr., A. A., Strickland III, A. J., Gamble, J. E. (2010). Crafting and Executing Strategy, (17 ${ }^{\text {th }}$ ed.). New York: McGraw-Hill Irwin.

Tsai, August. (2010). An Integrated e-Learning Solution in Hospitals. Journal of Global Business Issues. Diakses $28 \quad$ November dari http://proquest.umi.com/pqdweb?index $=8 \&$ did $=2198231821 \&$ SrchMode $=1 \&$ sid $=1 \&$ Fmt $=2 \&$ VInst=PROD\&VType=PQD\&RQT=309\&VName=PQD\&TS=1290947651\&clientId=68814. 